УДК 372.881.1

DOI:

Галина Мельник, кандидат педагогічних наук, доиент кафедри технологічної та професійної освіти Дрогобицького державного педагогічного університету імені Івана Франка Галина Ліщинська-Кравець, старший викладач кафедри технологічної та професійної освіти Дрогобицького державного педагогічного університету імені Івана Франка

Надія Кузан, кандидат педагогічних наук, доиент кафедри технологічної та професійної освіти Дрогобицького державного педагогічного університету імені Івана Франка

\title{
ЗАСТОСУВАННЯ СУЧАСНИХ ТЕХНОЛОГІЙ НАВЧАННЯ ПРИ ВИВЧЕННІ ХУДОЖНЬОЇ ВИШИВКИ
}

У статті розкрито специфіку організаиії процесу навчання студентів педагогічного університету технології вишивки. На основі аналізу результатів педагогічних досліджень вітчизняних і зарубіжних учених узагальнено практичний досвід формування творчого потенціалу молоді під час навчання. Методичні аспекти використання технології веб-квестів описані спільно з традиційними методами навчання. Усе це сприяе розвитку пізнавальної активності майбутніх вчителів, стимулює вдосконалення їх уваги, пам'яті, мислення, формування навичок роботи в колективі, поліпшення особистих якостей і самого процесу діяльності.

Ключові слова: сучасні технологї навчання; освітній прочес; веб-квест; мистецтво вишивання; студенти.

$\operatorname{Iim} .5$.

Halyna Melnyk, Ph.D.(Pedagogy), Associate Professor of the Technological and Vocational Education Department Drohobych Ivan Franko State Pedagogical University Halyna Lishchynska-Kravets, Senior Lecturer of the Technological and Vocational Education Department Drohobych Ivan Franko State Pedagogical University

Nadiya Kusan, Ph.D.(Pedagogy), Associate Professor of the Technological and Vocational Education Department Drohobych Ivan Franko State Pedagogical University

\section{APPLICATION OF MODERN TECHNOLOGIES OF EDUCATION} IN THE STUDY OF ARTISTIC EMBROIDERY

The article reveals the specifics of the organization of the teaching process of the pedagogical university of embroidery technology. The use of modern innovative techniques in the process of preparing future teachers of labor education and technologies contributes to improving the quality of their education, the formation of a cognitive interest of young people and the development of relevant competencies. For a young man, it is important not only to satisfy its cognitive needs, but also social needs in communication, psychological needs of respect for their own feeling of dignity, to their feelings and experiences, interests and abilities and no evidence.

On the basis of the analysis of the study of domestic and foreign scientists from pedagogical theory, the practical experience of forming creative potential of young people is summarized. The emergence of new innovative techniques contributes to this. Students find interest in all new, extraordinary, bright and impressive. The unusual task contributes to the concentration and switching attention, changes the course of thoughts, the student begins to think not only logically, but also abstract, creatively, which, in turn, contributes to the development of higher forms of thinking. The development of logical thinking, memory, attention, imagination, observation, informative skills increases the general level of awareness of future teachers, because they need to be properly and quickly influenced, acting organized, taking into account circumstances and existing resources.

It is, web quests contribute to the development of students with skills that are needed by a person of the XXI century. This ability to navigate in a huge flow of information, ability to analyze, think independently and creatively, objectively assess their achievements, ability to work in a team, keep up with time. Methodological aspects of using web quest technology are described in conjunction with traditional learning methods. All this contributes to the development of the cognitive activity of future teachers, stimulates improvement of their attention, memory, thinking, forming skills in the team, improving personal qualities and the process itself.

Keywords: modern training technologies; educational process; web quest; art of embroidery; students. 
Професійне зростання педагога завжди пов'язане з пошуком. Нині відкриваються все нові й нові можливості Інтернету: віртуальні екскурсії, спільні проєкти тощо. Щоб досягти ефективного поєднання власних педагогічних знахідок і освітніх Інтернет-ресурсів необхідна велика й цілеспрямована підготовка. А найголовніше, бажання викладачів удосконалювати педагогічну діяльність. Талант і рівень кваліфікації педагога запорука успіху в просуванні нових технологій. Саме педагогічні працівники повинні стати основною творчою силою впровадження Інтернет-технологій в сферу освіти та життя суспільства загалом.

Сучасний Інтернет пропонує багато ресурсів для використання в освітніх цілях: заняття в режимі online, peсурси для викладачів, ресурси для студентів, online-проєкти. Немає потреби переконувати у тому, що така інформаційна база має бути використана професійно і раціонально. Це вимагає усвідомлення самими викладачами значущості такого потенціалу і активного залучення Інтернет-ресурсів у свою професійну діяльність для досягнення кращих, вагоміших результатів у навчанні майбутніх фахівців.

Аналіз досліджень 3 проблеми. Проблеми застосування сучасних технологій навчання та вивчення специфіки їх використання в освітньому процесі розглядали у своїх дослідженнях В. Биков, Б. Гершунський, М. Жалдак, О. Коберник, Н. Морзе, С. Полат, Г. Терещук та ін. Проблемами розробки і застосування веб-квестів в освітньому процесі активно займаються як зарубіжні, так і вітчизняні фахівці: Б. Додж, Т. Марч, І. Албегова, О. Гапеєва, Я. Биховський, Р. Гуревич, В. Дивак, М. Кадемія, Н. Кононец, Н. Ніколаєва, І С. Сокол, Г. Шаматонова та ін. Розробка педагогами новітніх дидактичних матеріалів знайшла відображення у працях А. Горемичкіна, М. Гаврілова, С. Ступіної.

Мета статті полягає у розкритті сутності сучасної веб-квест технології та педагогічних можливостях іï застосування під час вивчення художньої вишивки.

Виклад основного матеріалу. Викладач може використовувати ресурси мережі Інтернет у такий спосіб: самоосвіта, самостійне підвищення своєї кваліфікації на основі інформації, що міститься в мережі, вивчення досвіду своїх колег; отримання інформації про новітні педагогічні технології; використання на заняттях i позанавчальних заходах методичних i дидактичних матеріалів, наявних у мережі; розробка власних матеріалів і публікація їх у мережі; участь в заочних конференціях, конкурсах, вебінарах тощо; пошук однодумців і колег в інших регіонах, листування і т. ін.
Вагомим чинником удосконалення форм i методів навчання, забезпечення поступового переходу від інформативного викладання, що базується на запам'ятовуванні, до проблемнопошукового, котре потребує досконалого володіння знаннями, стала інтенсифікація освітнього процесу через застосування технічних засобів, упровадження ділових ігор, веб-квестів у систему занять. Сучасний рівень розвитку інформаційних технологій надає широкі можливості щодо активізації та підвищення продуктивності навчання.

Сьогодні спостерігається небажання молоді здобувати знання, відсутність інтересу та мотивації до навчання. Як часто ми чуємо фрази “не хоче вчитися”, “міг би прекрасно навчатися, а бажання не має”. Виникає суперечність між світом закладу освіти і сучасним світом молоді. Світ освітнього закладу включає: традиційну систему навчання, звичайні “стандартні” заняття, застосування підручника, презентації, неефективних форм, методів навчання. Що ж включає в себе сучасний світ молоді? Це вік інформатизації, комп'ютеризації, інновації, практико-орієнтованого навчання і багато іншого.

Мабуть, багатьом знайоме відчуття, що час навколо зупинився, а ви цілком і повністю віддаєтеся роботі або якомусь заняттю й готові здолати гори для досягнення результату. При цьому час летить зовсім непомітно, індивідуальність розчиняється, свідомість і діяльність зливаються в одне. У стані “потоку” будь-яке рішення легко, плавно й безперешкодно приводить до іншого рішення. Потоковий стан (англ. - flow) - стан, в якому людина повністю включена в те, чим займається, характеризується зосередженням, повним залученням і націленістю на успіх у процесі діяльності. Розв'язання проблем відбувається швидко, оскільки людина відчуває:

- задоволення від перемоги;

- відсутність “страху” програшу, адже усе можна розпочати з початку;

- захоплення цікавим процесом.

Однією з вимог освітнього процесу є те, що навчання має бути цікавим для молодої людини. Тому у своєму педагогічному арсеналі викладач весь час повинен знаходити щось нове, щоб спонукати студентів до пошуку бажаної інформації, якісного освоєння нової теми тощо. На допомогу можуть прийти такі форм роботи, які використовуються в музейній, театральній педагогіці, роботі гуртків, психологічних тренінгах. Серед таких форм, які ще мало використовується в освіті, але популярні за ії межами, є квест.

Квест(quest-англ.)-цетривалий цілеспрямований 


\section{ЗАСТОСУВАННЯ СУЧАСНИХ ТЕХНОЛОГІЙ НАВЧАННЯ ПРИ ВИВЧЕННІ ХУДОЖНЬОЇ ВИШИВКИ}

пошук, який може бути пов'язаний з прикладами або грою; він також слугує для позначення одного з різновидів комп'ютерних ігор [3].

Квест є своєрідним різновидом інтелектуальнологічних активних ігор, синонімом для активного відпочинку. Це ігрова форма групового виконання завдань, яка має довгу історію розвитку, багато випадків використання і чимало позитивних моментів.

Під час квесту учасники (студенти) розгадують цікаві, несподівані загадки (завдання). Це характеризує квест як розумову гру, яка поєднує у собі елементи гри “Що? Де? Коли?” з інтригою “Острову скарбів”. Ця цікава, бадьора гра передбачає прояв розумових і фізичних зусиль учасників, використання їх вигадливості, вияв артистизму, спільних зусиль команди щодо розв'язання поставлених завдання.

На сьогодні не існує єдиного теоретичного підходу щодо використання терміна “Веб-квест". Це і проблемне завдання з елементами рольової гри; це й Інтернет-пошук, метою якого є навчання, тобто отримання нових знань, закріплення наявних знань та інших навичок з певного предмету; це й новітня форма проведення заняття, що спрямоване на розвиток пізнавальної, дослідницької практики студентів, й на котрому вагома частина інформації здобувається засобами Інтернету [1]. Розглядають веб-квест і як інформаційно-навчальну технологію, мета якоїсамостійний пошук учнями (студентами) інформації, необхідної для виконання поставленого завдання; і як самостійний вид навчальних проєктів [2].

Впровадження веб-квестів у освітній процес:

- допомагає викладачеві мотивувати студентів і залучати їх до навчання;

- розвиває різні розумові навички, просторову уяву та реакцію;

- дозволяє молоді навчатися в інтерактивному середовищі, в якому вони можуть тренуватися, робити помилки та виправляти їх;

- може містити практичні приклади понять, які було б важко пояснити;

- дозволяє викладачу організувати самостійну роботу студентів тощо.

Отже, елементи гри здатні зробити будь-який процес (навчання або роботу) цікавим. Кожна особа, залучена до “гри” відчуває себе частиною певної спільноти. Ігрові форми роблять процес навчання захопливим та цікавим, а змагання $\mathrm{i}$ винагорода за здобуті досягнення дозволяють учасникам не тільки підвищити свій статус і отримати ще одну форму самовираження, а й отримати стимул до прояву наполегливості, розвитку творчих здібностей.
У процесі роботи над веб-квестом викладач перестає бути основним джерелом знань для студентів. Він формулює завдання, визначає джерела та підшуковує посилання на Інтернерресурси, виконує дорадчу роль, створює освітнє середовище.

Запровадження веб-квест технології у закладі освіти дає змогу створювати цілісну дидактичну конструкцію, яка передбачає унікальну форму навчання, зміст, методи викладання і контролю, віддалено керувати самостійною діяльністю студентів у підготовленому та дидактично структурованому online-cередовищі, що забезпечує необхідний процес їх занурення у середовище інформації з одночасним освоєнням методів пошуково-конструктивної роботи у поєднанні з проблемними, пошуковими, ігровими, інтерактивними, командними методами навчання.

Квест дає змогу розвивати активне пізнання на заняттях та в позанавчальний час, сприяє розвитку мислення, допомагає долати проблеми та труднощі, зокрема: вирішувати, розплутувати, придумувати, уміти застосовувати свої знання на практиці у нестандартних ситуаціях, вчить мислити логічно, розвиває інтерактивні здібності.

В ідеалі, квест - це командна гра, для якої потрібна спільна координації усіх дій між гравцями. Доцільно проводити квест у групах, попередньо визначивши назву команди-групи. Тут наявні співпереживання, суперництво, підтримка гравців своєї команди тощо.

Веб-квести оптимально застосовувати для роботи у мінігрупах. Проте є веб-квести, призначені для виконання окремими студентами. Додатковою мотивацією при реалізації веб-квесту може бути вибір певної ролі [5].

Вибираючи форму веб-квесту для організації навчальної діяльності студентів, варто керуватися такими рекомендаціями [4]: 1) тема веб-квесту має відповідати змісту навчальної дисципліни і передбачати формування компетенцій, визначених освітньою програмою; 2) веб-квест має містити оптимально доцільну кількість можливих ресурсів Інтернет; 3) веб-квест має надавати можливість студентам розглядати питання теми з різних точок зору, стимулюючи тим самим розвиток критичного мислення; 4) структура веб-квесту має передбачати як групову, так й індивідуальну роботу; 5) методика проведення веб-квесту має враховувати особливості конкретної навчальної дисципліни та готовність студентів до роботи.

Робота над квестом передбачає такі етапи: початковий (командний); рольовий (виконання завдань); заключний. 
Розглянемо приклад короткострокового вебквесту на тему “Створення композиції майбутнього виробу".

Квест можна проводити як у майстерні, так і у музейній світлиці.

Мета: узагальнення знань про композицію, іiі колорит, основні мотиви, види орнаменту; зрозуміти, як передається настрій у композиції; розвивати увагу, пам'ять, мислення, вміння працювати у команді, толерантність; розвивати інтерес до декоративно-ужиткового мистецтва, вміння сприймати і насолоджуватися ним.

Завдання: навчитися розрізняти види композиційних побудов; навчитися використовувати дидактичний матеріал; розвивати вміння розв'язувати головоломки, кросворди, загадки; формувати здатність виконувати цю роботу протягом певного часу; формувати вміння працювати в команді, підтримуючи один одного; навчитися виконувати ескізи композиції.

Обладнання: плакати із загадками, кросвордами, зразки композиційних побудов, картотека мотивів, натуральні зображення рослинних мотивів, картки "Етапи створення композиції”, “Види орнаментальних композицій”, карта маршруту, Інтернет-ресурси.

Карта маршруту

Зупинка 1. Композиція.

Зупинка 2. Кольори.

Зупинка 3. Природні мотиви.

Зупинка 4. Стилізація малюнка.

Зупинка 5. Види орнаменту.

Зупинка 6. Побудова композиції виробу.

Початковий (командний) етап

Перш, ніж розділити студентів на групи, їх ознайомлюють із загальними відомостями з теми заняття, усвідомлюючи проблему майбутнього проєкту (мотивація навчально-пізнавальної діяльності). Студенти обирають майбутні ролі (групи “Фізики”, “Біологи”, “Етнографи”, “Художники”, “Мистецтвознавці”, “Дизайнери”) та вивчають основні поняття та терміни з обраної теми.

Рольовий етап

Студенти, відповідно до обраних ролей, одночасно виконують завдання. Оскільки мета роботи не змагальна, то в процесі роботи над вебквестом відбувається взаємне навчання членів групи. Команда спільно підбиває підсумки виконання кожного завдання, учасники обмінюються матеріалами для досягнення спільної мети.

Зупинка 1. Композиція

1. Складіть слово 3 даних літер і вгадайте назву першої зупинки: Я-1, К-1, П-1, И-1, I-1, М-1, О-2, 3-1, Ц-1 (композиція).
2. Слово латинського походження, що означає “складання, зв'язування, з'єднання”.

3. Побудова художнього твору, яка обумовлена його змістом, призначенням і характером.

4. Сам твір, тобто кінцевий результат діяльності художника.

Зупинка 2. Кольори

Завдання для групи “Фізики”

1. Відгадайте загадку: “3 чого складається веселка?"

Відгадка - це назва другої зупинки (кольори).

2. Підготуйте повідомлення:

1) “Як сонячне, електричне, місячне світло впливає на колір об'єктів?”

(Сонячне світло робить колір предметів світлішим; місячне - сірим, блідно-блакитним, світло-зеленим; електричне - світло-жовтим).

2) “Чи змінюється колір залежно від розташування елементів? Як?”

(На передньому плані важливу роль відіграють власні кольори; на дальньому - умовні).

3) Навіщо вам потрібно це знати?

(Щоб правильно використовувати нюанси кольору при створенні композиціі).

Зупинка 3. Природні мотиви

Завдання для групи “Біологи”

Наша Україна багата на цікаві зразки рослинного і тваринного світу.

Зробіть замальовки (фотографії) зразків рослинного (тваринного) світу. Опишіть їх характерні ознаки та особливості. За необхідності надайте консультативну допомогу своїй команді.

Завдання для групи “Етнографи”

3'ясуйте, які природні мотиви найчастіше зустрічаються на виробах різних видів декоративноужиткового мистецтва у вашому регіоні.

Звіт можна представити у вигляді спільної презентації в Power Point.

Зупинка 4. Стилізація малюнка

Завдання для групи "Художники”

Типовою рисою вишитого орнаменту є його стилізоване трактування.

Щоб продовжити виконання завдання вам потрібно закінчити речення:

1) Стилізація - це ...

Очікувана відповідь: Стилізація - це творча переробка форм реального світу з найбільшим художнім узагальненням.

2) Для стилізації спочатку виконують ...

Очікувана відповідь: Для стилізації спочатку виконують натуральні замальовки, в яких передаються найхарактерніші риси об'єкта, а потім послідовно спрощують їх, наближаючи до простих геометричних форм, або стилізують декоративну форму в технічний малюнок. 
3) Стилізуючи декоративну форму в технічний малюнок, приділяють особливу увагу ...

Очікувана відповідь: Стилізуючи декоративну форму в технічний малюнок, приділяють особливу увагу узагальненню природних форм, виявленню їхніх конструкційних особливостей (визначенню геометричної форми і правильному вибору техніки майбутньої вишивки).

Проаналізувавши послідовність стилізації візерунка, виконайте ескіз, виконавши такі завдання:

а) уважно роздивитися предмет зображення;

б) олівцем замалювати предмет зображення, дотримуючись пропорцій;

в) зобразити етапи стилізації малюнка;

г) підібрати кольори відповідно до обраної композиції, призначення, форми виробу та стилізації.

Звіт представити у вигляді альбому (слайдшоу, буклету) зі стилізованими природними мотивами (листками, квітами, гілками, деревами тощо).

Зупинка 5. Види орнаменту

Завдання для групи "Мистецтвознавці"

Користуючись Інтернет-ресурсами, зразками колекціями вишиваних виробів, каталогами виставок, музеїв, з'ясуйте які бувають види орнаментів.

Звіт може бути представлений у вигляді файлів та включати схеми, фотографії й інші матеріали.

Зупинка 6. Побудова композиції виробу

Завдання для групи “Дизайнери”

Оберіть орнамент, правильно розташуйте візерунок і створіть композицію для вишитої серветки (хустини) квадратної форми.

I підгрупа - асиметричне розміщення елементів на виробі.

II підгрупа - паралельне розміщення елементів на виробі.

III підгрупа - кутове розміщення елементів на виробі.

Заключний етап.

На етапі оформлення результатів діяльності відбувається осмислення проведеного дослідження. Робота передбачає відбір найбільш значущої інформації та представлення ії у вигляді слайд-шоу, буклету, анімації, постера або фоторепортажу. Обговорення результатів роботи над веб-квестом можна провести у вигляді конференцій, щоб студенти мали можливість представити свої результати і усвідомити значущість виконаної роботи.

Висновки. Усе вищезазначене дає змогу зробити висновок, що веб-квест - це технологія, яка має чітко поставлене дидактичне завдання, ігровий задум, керівника (наставника), чіткі правила та реалізується 3 метою підвищення пізнавальної активності учасників, розвитку їх творчого потенціалу, формування відповідних компетенцій і вміння працювати у команді.

\section{ЛІТЕРАТУРА}

1. Албегова И.Ф., Шаматонова Г.Л. Веб-квест какинновационнаяинформационно-коммуникационная технология в образовании: сущность и способы применения. Дистанциионное и виртуальное обучение. 2009. № 7. С. 7 - 12 .

2. Гуревич Р.С., Кадемія М.Ю. Веб-квест як інноваційна технологія навчання у вищій і середній школі. Вісник Луганського національного університету імені Тараса Шевченка. Серія: педагогічні науки. Луганськ: ЛНУ ім.Т.Шевченка, 2011. Ч. 1. Вип. 21(232). С. $36-45$.

3. Кадемія М.Ю., Шестопалюк О.В. Вебквест у підготовці майбутніх учителів : навчальнометодичний посібник. Вінниця : ТОВ Фірма "Планер", 2013. 155 с.

4. Нечитайлова Е.В. Веб-квесты как методика обучения на основе Интернет-ресурсов. Проблемь современного образования: Интернет журнал. 2012. №2. C. 147 - 155. URL: http://www.pmedu.ru/ res/2012_2_13.pdf.

5. Сокол І.М. Веб-квест як інноваційний метод формування творчої особистості. Освіта ma розвиток обдарованої особистості. 2013. № 2. C. 28-30. URL: http://nbuv.gov.ua/UJRN/ Otros_2013_2_8.

\section{REFERENCES}

1. Albegova, I.F. \& Shamotonova, G.L. (2009). Veb-kvest kak innovatsionnaya informatsionnokommunikatsionnaya tekhnologiya $\mathrm{v}$ obrazovanii: sushchnost i sposoby primeneniya [Web quest as an innovative information and communication technology in education: essence and methods of application]. Distance and virtual learning. No. 7. pp. $7-12$. [in Russian].

2. Hurevych, R.S. \& Kademiia M.Iu. (2011). Veb-kvest yak innovatsiina tekhnolohiia navchannia u vyshchii i serednii shkoli [Web-quest as an innovative learning technology in high school and high school]. Bulletin of Taras Shevchenko National University of Luhansk. Series: pedagogical sciences. Luhansk, part. 1. Vol. 21(232), pp. $36-$ 45. [in Ukrainian].

3. Kademiia, M.Iu. \& Shestopaliuk, O.V. (2013). Veb-kvest u pidhotovtsi maibutnikh uchyteliv : navchalno-metodychnyi posibnyk [Web-quest in the training of future teachers: a textbook]. Vinnytsia, 155 p. [in Ukrainian]. 
4. Nechitaylova, Ye.V. (2012). Veb-kvesty kak metodika obucheniya na osnove Internet-resursov [Web quests as a teaching method based on Internet resources]. Problems of modern education: Internet magazine. No.2. pp. 147 - 155. Available at: http://www.pmedu.ru/res/2012_2_13.pdf. [in Russian].
5. Sokol, I.M. (2013). Veb-kvest yak innovatsiinyi metod formuvannia tvorchoi osobystosti [Web-quest as an innovative method of forming a creative personality]. Education and development of gifted personality. No. 2. pp. 28-30. Available at: http:// nbuv.gov.ua/UJRN/Otros_2013_2_8. [in Ukrainian].

Стаття надійшла до редакції 23.12.2021

\section{УДК 378.147:[373.5.011.3-051:78]:001.895}

DOI:

Іван Заболотний, заслужений діяч мистецтвв України, професор кафедри хорового диригування, вокалу та методики музичного навчання Сумського державного педагогічного університету імені А.С. Макаренка Марина Петренко, кандидат педагогічних наук, доцент завідувач кафедри хорового диригування, вокалу та методики музичного навчання Сумського державного педагогічного університету імені А.С. Макаренка

\section{ТЕОРЕТИКО-МЕТОДОЛОГІЧНІ ОРІЕНТИРИ ОНОВЛЕННЯ ФАХОВОЇ ПІДГОТОВКИ УЧИТЕЛЯ МУЗИЧНОГО МИСТЕЦТВА}

У статті розглянуто теоретко-методологічні орієнтири фахової підготовки учителя музичного мистецтва. На прикладі освітнього процесу кафедри хорового диригування, вокалу та методики музичного навчання навчально-наукового інституту культури і мистецтв СумДПУ імені А. С. Макаренка визначено сучасні методологічні підходи, які сприяють ефективності фахової підготовки майбутніх учителів музичного мистеитва

Ключові слова: учитель музичного мистецтва; фахова підготовка; методологічні підходи, освітній nройec.

Jim. 10.

Ivan Zabolotnyi, Honored Art Worker of Ukraine, Professor of the Choral Conducting, Vocals and Methods of Music Education Department,

Sumy Anton Makarenko State Pedagogical University

Maryna Petrenko, Ph.D.(Pedagogy), Associate Professor, Head of the Choral Conducting, Vocals and Methods of Music Education Department,

Sumy Anton Makarenko State Pedagogical University

\section{THEORETICALAND METHODOLOGICAL GUIDELINES OF UPDATING THE MUSIC ART TEACHER'S PROFESSIONAL TRAINING}

The article considers the theoretical and methodological guidelines for updating of the music art teachers professional training. In order to study the specifics of the future music art teacher on the example of the educational process of the Choral Conducting, Vocals and Methods of Music Education Department of Sumy Anton Makarenko State Pedagogical University there are identified the modern methodological approaches that contribute to the effectiveness of music art teachers professional training, namely: innovative approach, competence approach, humanistic approach, axiological approach, integrated approach, personality-oriented approach, acmeological approach, hermeneutic approach, in the context of which the characteristic features of theoretical and methodological guidelines for updating of music art teachers' professional training are found.

The substantiation of scientific and methodological approaches, essence and content in the educational process revealed that the leading place belongs to the future music art teachers' professional training. It is proved that the crucial importance of the future music art teacher's professional activity includes two factors - the mobile application of existing valuable knowledge and skills, modern forms and methods of applying information and communication technologies. Thus, the described methodological approaches have their own content and contribute to the renewal of the music art teachers' professional training.

Summarizing the above mentioned, it can be concluded that certain methodological approaches affect the quality and effectiveness of the educational process of the future music art teachers' professional training. It was found that the theoretical and methodological basis in the music art teachers' training on the example of the 